\title{
Management of Funds and Economic Security in Universities in Cross River State
}

\author{
Odigwe Francisca $\mathbf{N}$. \\ Department of Educational Administration \& Planning \\ University of Calabar \\ Okoi, Ikpi Inyang \\ Department Of Educational Administration \& Planning \\ University Of Calabar \\ Ekaette, Samuel Okpon \\ Department Of Educational Administration \& Planning \\ University Of Calabar
}

\begin{abstract}
Recently, there have been reports on mismanagement and misappropriation of finances in universities. This study therefore, aimed at determining the relationship between management of funds and economic security in universities in Cross River State. The management of funds was examined in relation to internal audit system and budgetary control. Survey research design was adopted while the population of the study consisted of ninety (90) department heads from University of Calabar and Cross River State University of Technology (CRUTECH). Purposeful sampling technique was used and the sample size consisted of ninety departmental heads from the two universities. Questionnaire titled management of funds and economic security (MOFAESQ) was used. The reliability estimate was carried out using Cronbach reliability estimate (' $r$ ' -0.67 and ' $r$ ' - 0.74) Pearson Product moment correlation statistics was used for data analysis. The result of the findings revealed that there is a positive correlation between internal audit system, Budgeting control and economic security. It was therefore recommended that university management should ensure and establish an effective budgetary control system in order to control university expenditures. Moreso, university management should develop more strategies that will harness fully the various funds within the university.
\end{abstract}

Key words: Management, Funds, Economic Security, Management of Funds, Management of Funds in Universities

\section{INTRODUCTION AND BACKGROUND}

The nation's economy is always at the receiving end of the continued specter of insecurity in that country. Economic security is the condition of having a stable income or other resources to support a standard of living now and in the foreseeable future. It comprises basic social security, defined by access to the basic needs pertaining to health, education, information and social protection, as well as work-related security.

Economic development involves increasing the production capacity of the country and the material wellbeing of the people. It should reflect positively on the nation's infrastructure, educational and health facilities and above all security. According to Atiku (2011), universities should see themselves as partners in economic development and the process of nationbuilding. For instance universities should organize teaching and research in a manner that tries 
to consciously meet the development needs of the country. It should also use its enrollment procedures and intellectual and cultural environment to consciously promote the goals of nation -building.

Fund management is the subset of management skill that focuses on generating financial information that can be used to improve decision making. For profit organizations, an underlying goal of those decisions is to maximize the wealth of the owners of the organization while in public service organizations like the specialized federal universities, the decisions are oriented towards achieving the various goals of the organization while maintaining a $\mathrm{s}$ satisfactory financial situation.

According to Aknisulere (2005) fund management connotes responsibility for obtaining and effectively utilizing the funds necessary for the efficient operation of an enterprise. It therefore covers all areas involved in ensuring that financial resources are obtained and used in the most effective way to guarantee attainment of the objectives organization.

Management of funds from the government and other sources is a very important function in any organization. No matter how adequate or inadequate funds made available to specialized universities are, such funds will be of little value if they are spent on wasteful and unproductive ventures by its management. Prudent management of funds is to ensure orderliness and control in its allocation and application (Abdu-Hamid 2005).

According to Abdul-Hamid (2005), to ensure fiscal stability and prudent fund management, the regulation and control of university funds must be placed in the hands of the highest authority that is, governing council.

Effective management entails understanding of what the critical functions of the institution are in the context of goals, capacity for determining the critical resources and resource levels required for the effective discharge of these functions, the capacity for deploying resources in a creative way to eliminate misapplication and wastage etc.

Adefia (2005) identifies poor funding as one of the major problems of fund management as it often forces universities to alter their programs without due regard to budget submissions. Accordingly this can lead to loss of confidence in budgeting, as faculties/departments wait for their allocations based on funds at the disposals of the university. Part of the effect of this will be the abandonment of in-depth planning and control, with the claim that they would not be considered for anything. The role of Internal Auditing is to determine whether the procedures and controls that management operates are being complied with and their adequacy. Etcher (2009) posits that Internal auditing is a dynamic profession involved in helping organizations achieve their objectives. It is also concerned with evaluating and improving the effectiveness of risk management, control and governance processes in an organization.

According to Mgbekem (2004) strategies for the effective management of funds include making use of competent, experienced and reliable leadership, efficient internal and external audit system, establishment of sound and reliable accounting systems, budgeting and budgeting control and computerization of the system. This study will adopt two strategies as variables for effective management of funds in Nigerian universities (a) Internal audit system and (b) budgetary control. The internal audit system, according to Mgbekem (2004) engages in pre auditing and post auditing. Pre auditing ensures that all purchases are vital and the price on items represent true market value. Post expenditure auditing is directed at ensuring that items 
for which money has been disbursed have been paid by the accounting officer. Ambrose. (2004) observed that, the internal audit unit in federal universities undertakes continuous examination of the work of the bursary to ensure that proper records are maintained in accordance with the prescribed procedures. It also carries out a prepayment audit of all payment transactions and occasionally undertakes special investigation.

Budget control is also another strategy for management of funds in universities. Mgbekem (2004) maintains that a budget safeguards careless expenditure because it captures only items which require expenditure. It monitors expenditure activities to detect deviation from a planned programme. Johnson (1992) also stated that a budget serves as a means of achieving the objectives of an organization. The objectives of a well performing budget involve resource allocation, control of aggregate spending and deficit, facilitating strategic projection of expenditure across policies and programs. Ultimately, it encourages better use of budgeted resources to achieve outcomes and produce outputs at the lowest possible cost.

Odubu (1997) in his own view stated that budgetary control involves comparing the actual operation with the budget to determine if the plans are being carried out and if not to ascertain the reasons for deviations so that corrective measures can be undertaken. Some of the corrective measures include coordinating the various departments of the organization and establishing responsibilities, comparing actual performance with that budgeted and acting upon these results to achieve maximum profitability. It helps to control expenditure because of its monitoring nature.

The productive efficiency of a government establishment that deals purely on teaching and research work may be difficult to measure annually unlike a profit making and business organization. The budgetary control system helps to measure performance by comparing actual result with budget. With proper planning and the necessary controls, funds will be judiciously utilized and university management can achieve their goals. It is against this background that this study aimed at determining the relationship between effective management of funds and economic security in universities in Cross River State.

\section{Statement of The problem}

The state of tertiary institutions in Nigeria can be described as that of criseauy sustained by the persistent disequilibrium between supply of and demand for educational services. Universities engage in teaching, research and development which have been identified as indispensable for national economic development. However, complaints from the management of specialized universities show that funds to these universities are inadequate (Idachaba 1988).

The government on its part has frowned at the poor management of funds in universities and has therefore called on specialized federal universities to justify the huge government investment on them (Obasanjo 2004). Could the challenge of physical facilities, graduate output and research output be responsible for the poor management of available funds in the university? Therefore, this study investigated the extent to which effective management of funds relate to economic security in universities in Cross River State?

\section{Purpose of the study}

The purpose of the study is to determine whether effective management of funds relate to economic securities in Universities in Cross River State. 
Specifically, the study aimed at determining

1. To what extent does efficient internal audit system relate to economic security

2. To what extent does budgetary control relate to economic security in universities.

\section{Hypotheses}

The following hypothesis were stated to direct this study

H01: There is no significant relationship between efficient internal audit system and economic security in universities in Cross River State, Nigeria.

H02: There is no significant relationship between efficient budgetary control and economic security in universities in Cross River State

\section{METHODOLOGY}

This study adopted a survey design and was carried out in the two Universities in Cross River State (University of Calabar and Cross River State University of Technology (CRUTECH). Purposive sampling technique was adopted to select the sample population from a total population of Ninety Departmental Heads in the two institutions A questionnaire instrument titled 'Management of Funds and Economic Security in Universities' (EMFAECSQ) was designed by the researcher for the study. The questionnaire titled management of funds (MOFAESQ) consisted of two parts A and B. Part A elicited demographic information about each head of department such as sex, years of experience, marital status etc. Part B requested information about internal audit system, budgetary control and economic security. Eighteen (18) items statement were used.

The content validity of the instruments was determined by experts in tests and measurement who matched each item of the instruments with the variable used in order to determine whether or not the instruments actually measured what they were supposed to measure. In conducting the reliability of the study Cronbach alpha reliability estimate was used. The reliability sowed ' $r$ ' $=0.67$ and 0.74 .

The questionnaire was administered to heads of the department in the university of Calabar and Cross River University of Technology (CRUTECH). Pearson product moment correlation statistics was used for data analysis. The result is presented below:

\section{Hypothesis 1}

\section{RESULT AND FINDINGS}

There is no significant relationship between internal audit system and economic security in University in Cross Rive State, Nigeria

Table 1: Pearson Product Moment Correlation Analysis on the relationship between efficient internal and audit system and economic security in Universities.

\begin{tabular}{lcccccc} 
Variables & $\mathbf{N}$ & $\overline{\mathbf{X}}$ & SD & df & Crit.r & Cal. r \\
\hline Efficient internal and audit system & 90 & 14.48 & 2.73 & & & \\
& & & & 88 & 0.205 & 0.53 \\
Economic security & & 14.75 & 2.36 & & & \\
\hline
\end{tabular}

$\mathrm{R}(90)=0.53, \mathrm{p}<0.05$.

The result of this table revealed that there is a significant relationship between efficient internal audit system and economic security in Universities. 


\section{Hypothesis 2}

There is no significant relationship between efficient budgetary control and economic security in Universities in Cross River State, Nigeria.

Table 2: Pearson Product Moment Correlation Analysis on the relationships between efficient budgetary control and economic security in Universities.

\begin{tabular}{lllllll}
\hline Variables & N & X & SD & df & Crit.r & Cal. r \\
\hline Efficient budgetary control & 90 & 15.21 & 3.04 & & & \\
Economic security & & & & 88 & 0.205 & 0.71 \\
\hline
\end{tabular}

$R(90)=0.71, p<0.05$

The result in table 2 reveals that there is a significant relationship between efficient budgetary control and economic security in Universities. $R(90)=0.71, p<0.05$.

\section{DISCUSSION OF RESULTS}

The result of this study revealed that there is a significant relationship between an efficient internal audit system and economic security in Universities. The result revealed a positive correlation of $r(90)=0.53$. the null hypothesis was rejected while the alternate hypothesis was retained. The result of this finding is in line with the findings of Mgbekem (2004), Kolade and Peter (1984) who posited that internal audit is an independent appraisal activity within the organization for the critical review of its accounting, financial and other operations as a basis for service to management. Accordingly, they added that it is a management control mechanism which functions by measuring and evaluating the effectiveness of other controls.

Ambrose (2004) maintained that the internal audit is to ensure that income is raised in accordance with relevant statutes, expenditure is legal under the relevant statutes and that it has been authorized by the appropriate committee.. He further observed that the internal audit unit in Federal Universities undertakes continuous examination of the work of the bursary to ensure that proper records are maintained in accordance with the prescribed procedures.

The result of hypothesis two revealed that there is a significant relationship between effective budgetary control and economic security. The result revealed a significant positive relationship of $r(90)=0.71, p<-.05$. This finding corroborates the views of Mgbekem (2004) who stated that a budget safeguards careless expenditure because it shows items which require expenditure. It monitors expenditure activities to detect deviation from a planned programme. Odubu (1997) in consonance with the result of this study stated that budgetary control involves the actual operation with the budget to determine if the plans are being carried out and if not to ascertain the reasons for deviations so that corrective measures can be taken by the management. The budgetary control system should cover the preparation of the budget, coordinating the various departments of the organization and establishing responsibilities, comparing actual performance with that budgeted and acting upon these results to achieve maximum profitability. It also helps to control expenditure because of its monitoring nature.

\section{CONCLUSION}

Based on the findings of this research, the study concludes that effective management of funds using efficient internal audit system and efficient budgetary control have strong positive and direct effects on the economic security of any organization. 


\section{RECOMMENDATIONS}

The following recommendations are made arising from this study.

1. University management should develop more strategies that will harness fully the various funds within the University.

2. University management should ensure and establish an effective budgetary control system in order to control University expenditure.

3. Government should increase University funds in order to help management achieve the objectives of tertiary institutions.

4. University management should ensure strict monitoring and application of internally generated revenue to enhance development of the school.

\section{References}

Abdul-Hamid, K. A. (2005). Effective Financial Management Budget Implementation and Control in Higher Education: Paper Presented at the National Conference of Association of Nigerian University Professional Administration (ANUPA) ABU, Zaria. ?pages

Adefic, S. (2005). The relationship between University (Central) Management and Faculties Departments: Some Observations. Workshop Paper presented at the capacity Building Workshop for Deans, Director Heads of Department and Faculty Officers, Zaria.? Pages.

Akinsulere, O. (2005). Financial Management 3rd Edition. Elcoda Venture Limited Apapa, Lagos.

Ambros, F. D. (2004). Educational Costing and Financial in Developing Countries Lescington Publishers.. Pages..?

Atiku, A. (2011). Addressing the Socio-Economic Dimensions of Nigeria's Internal Security Challenged. A Speech delivered at the Annual Founders Day Celebration of the American University of Nigeria, Yola on November 19, 2011.

Eucher J. C. (2009). Educational Costing and Financing in Developing Countries on Subsoharan Washington.

Johnson, I. E. (1992). Management Control in Public Sector. The Nigerian Accounts Journal Chartered Accountant of Nigeria Oct/Dec. Vol xxv. No: 4.

Kolade, O. and Peter, N. (1984). Financial Management in the Nigerian Public Sector Pitman Books Limited 128, Long Acre London.

Kwanishe, G. (2005). Issues in Resources Mobilization, Allocation and Accountability in Nigeria Higher Education (A Paper for ANUPA 2005 Conference).

Mgbekem, S. J. A (2004). Management of University Education in Nigeria. University of Calabar Press, Calabar.

Obasanjo, A. O. (2004). University System Chronicle.

Odubu, J. E. (1997). Funding and Utilization of Funds in Nigeria Research Institute. A case study of selected Institutions M.Sc Thesis unpublished ABU Zaria.

Ronald M. Copeland (2010). Management Accounting New York sent from my iPad 